\title{
ANALISIS PENERAPAN STANDAR AKUNTANSI KEUANGAN ENTITAS TANPA AKUNTABILITAS PUBLIK (SAK ETAP) DALAM PENYAJIAN LAPORAN KEUANGAN PADA KOPERASI PEGAWAI REPUBLIK INDONESIA (KPRI) GELORA PENDIDIKAN KOTA TOMOHON
}

\author{
Renaldy Fernando Rolos ${ }^{1}$ \\ Jullie J Sondakh ${ }^{2}$ \\ Robert Lambey ${ }^{3}$ \\ ${ }^{1,2}$ Fakultas Ekonomi dan Bisnis Jurusan Akuntansi \\ Universitas Sam Ratulangi Manado
}

Email: ${ }^{1}$ aldy_fernando13@yahoo.com

2aldyjuventini13@gmail.com

\begin{abstract}
Financial report are a formal report of the financial activities of an entity including a cooperative and prepared as a responsibility of management to internal and eksternal parties. The existing Generally Accepted Accounting Standards are yet a diffifult to be implemented by a cooperative because the existing standards more devoted to a large entities and have a public accountability. IAI has issued financial Accounting Standards of an entity without Public Accountability or know as SAK ETAP. SAK ETAP is intended to accommodate needs of an entity, wich significantly does not have any accountability, to operate as such Small and Medium Enteprises (SMEs) and a cooperative. This research is aimed to evaluate SAK ETAP implementing in Financial statement of KPRI "Gelora Pendidikan" Kota Tomohon. KPRI "Gelora Pendidikan" Kota Tomohon is a cooperative in savings and loans bussiness. Research method are descriptive comparative by comparing primary and secondary data. It is found that a cooperation's financial report as of 2015 not yet complied with SAK ETAP priciples and a few report have not presented like Cash flow statement and Statement of changes in equity. It is cause by limitied of accounting skills gained by its human resources.
\end{abstract}

Keywords :SAK ETAP, Finacial Statement.

\section{Latar Belakang}

\section{PENDAHULUAN}

Pembangunan yang dilaksanakan bangsa Indonesia merupakan wujud dari usaha untuk mencapai tujuan nasional. Tujuan nasional bangsa Indonesia sendiri tercermin dalam Undang-Undang Dasar (UUD) 1945. Dan khususnya tujuan bangsa dalam bidang ekonomi tertuang dalam pasal 33 ayat 1 yang menyatakan bahwa "perekonomian disusun sebagai usaha bersama berdasarkan atas asas kekeluargaan". Dalam penjelasan UndangUndang Dasar 1945 disebutkan bahwa usaha yang sesuai dengan pasal tersebut adalah koperasi. (Mulyani,2013). Koperasi adalah milik semua anggota yang telah memberikan dananya untuk dipakai sebagai modal dalam kegiatan operasional koperasi tersebut. Dalam menjalankan kegiatan usahanya kekuasaan tertinggi ada pada rapat anggota, baik itu rapat bulanan maupun Rapat Anggota Tahunan (RAT) (Sitorus, 2011).

Koperasi yang diharapkan dapat menjadi tonggak utama perekonomian Indonesia mengalami berbagai hambatan dalam pelaksanaan kegiatannya misalnya kekurangan dana untuk operasional koperasi. Kurangnya kemampuan pelaku koperasi dalam bidang pengelolaan usaha juga termasuk kendala yang dihadapi koperasi, selain itu rendahnya pendidikan serta kurangnya pengalaman dalam bidang akuntansi menjadi kendala yang harus dihadapi oleh koperasi. Sebagai sebuah lembaga ekonomi, yang nantinya akan menghasilkan sebuah laporan keuangan, koperasi sudah dipastikan akan berhubungan dengan berbagai pihak yang memiliki kepentingan terhadap hasil kinerja mereka (Khafid 2012). Oleh karena itu, agar koperasi bisa berkembang dan menjadi seperti yang diharapkan, koperasi harus berpedoman pada suatu standar yang dibuat untuk mengatur pengelolaan koperasi itu sendiri, sehingga dalam pengelolaannya, manajemen koperasi memiliki tuntunan agar dapat mejadikan koperasi tersebut menjadi lebih baik.

Standar Akuntansi Keuangan Entitas Tanpa Akuntabilitas Publik (SAK ETAP) ditetapkan oleh Ikatan Akuntan Indonesia (IAI) untuk mempermudah perusahaan dan menengah dalam menyusun laporan keuangannya. Seiring dengan dihapus-kannya PSAK No. 27 tentang Perkoperasian dan diberlakukannya SAK ETAP, maka koperasi-koperasi yang ada di Indonesia diarahkan untuk menerapkan SAK ETAP dalam penyajian laporan keuangannya. SAK ETAP adalah standar yang mengatur tentang perlakuan akuntansi 
terhadap UMKM dan koperasi yang ada di Indonesia, tetapi semua kegiatan koperasi juga berpedoman pada undang-undang dan peraturan pemerintah terbaru yang dikeluarkan oleh menteri terkait dalam hal ini Peraturan Menteri Koperasi dan Usaha Kecil dan Menengah (K-UKM) Republik Indonesia No 12 Tahun 2015, tentang Pedoman Umum Akuntansi Koperasi.

Koperasi Pegawai Republik Indonesia (KPRI) adalah salah satu jenis koperasi yang ada di Indonesia. Koperasi ini beranggotakan para pegawai negeri yang berada disuatu instansi pemerintahan atau para pegawaipegawai negeri di suatu kota atau kabupaten. KPRI adalah salah satu jenis koperasi yang keberadaannya cukup banyak di Indonesia ini dan tersebar di setiap kabupaten dan kota, sehingga penulis tertarik untuk menjadikan KPRI sebagai objek penelitian skripsi penulis.

\section{Tujuan Penelitian}

Tujuan yang ingin dicapai dalam penelitian ini adalah untuk mengetahui kesesuian penyajian Laporan Keuangan Koperasi Pegawai Republik Indonesia (KPRI) "Gelora Pendidikan dengan Standar Akuntansi Keuangan Entitas tanpa akuntabilitas publik (SAK ETAP) dan Peraturan Menteri Koperasi dan Usaha Kecil dan Menengah Republik Indonesia No 12 Tahun 2015, tentang Pedoman Umum Akuntansi Koperasi.

\section{Akuntansi}

\section{TINJAUAN PUSTAKA}

Akuntansi adalah proses mengenal, mengukur, dan menemukan hubungan berbagai informasi ekonomi agar pengguna informasi dapat menentukan pertimbangan dan keputusan yang tepat. Secara konkret proses tersebut berupa tindakan mencatat, mengklasifikasi, menganalisis, dan melaporkan berbagai transaksi sehingga dapat dipahami oleh para pengguna informasi. Fungsi utama akuntansi adalah sebagai informasi keuangan suatu perusahaan atau organisasi. Dari laporan akuntansi kita bisa melihat posisi keuangan suatu perusahaan beserta perubahan yang terjadi di dalamnya. Tujuan akuntansi adalah menyajikan informasi ekonomi dari suatu kesatuan ekonomi atau perusahaan kepada pihak-pihak yang berkepentingan, baik pihak di dalam perusahaan maupun pihak di luar perusahaan. (Kieso et al 2010 : 2)

\section{Akuntansi Keuangan}

Akuntansi keuangan (financial accounting) adalah sebuah proses yang berakhir pada pembuatan laporan keuangan menyangkut perusahaan secara keseluruhan untuk digunakan baik oleh pihak-pihak internal maupun pihak eksternal (Shok, 2013). Keluaran utama akuntansi keuangan adalah laporan keuangan. JM Jastra (2011) menyatakan bahwa akuntansi keuangan akan menghasilkan sebuah laporan keuangan yang menggambarkan keadaan finansial sebuah entitas. Akuntansi keuangan berorientasi pada pelaporan kepada pihak eksternal. Untuk itu diperlukan standar akuntansi yang dijadikan pedoman baik oleh penyusun maupun pembaca laporan keuangan.

\section{Koperasi}

Istilah koperasi sebenarnya berasal dari bahasa asing yaitu Co-Operation; dimana Co berarti bersama dan Operation berarti usaha. Secara harafiah koperasi dapat diartikan sebagai usaha bersama. Dalam UU Nomor 25 Tahun 1992 tentang perkoperasian, koperasi diartikan sebagai badan usaha yang beranggotakan orang-orang atau badan hukum koperasi dengan melandaskan kegiatannya berdasarkan prinsip koperasi sekaligus sebagai gerakan ekonomi rakyat yang berdasarkan atas asas kekeluargaan.

Adapun prinsip-prinsip dalam koperasi antara lain:

a. Bersifat sukarela dan terbuka.

b. Pengawasan oleh anggota secara demokratis

c. Partisipasi anggota dalam kegiatan ekonomi

d. Otonomi dan kemandirian

e. Pendidikan, pelatihan dan informasi

f. Kerjasama antar koperasi

g. Kepedulian terhadap masyarakat

Dalam koperasi dimensi kekuasaan tertinggi dalam menentukan kebijaksanaan usaha berada pada para anggota, melalui alat kelengkapan koperasi yang sebut "Rapat Anggota Tahunan". Sedangkan dalam badan usaha non koperasi kekuasan tertinggi berada pada para pemegang saham. Karakteristik utama koperasi yang membedakannya dengan badan usaha lain adalah bahwa anggota koperasi memiliki identitas ganda (the dual 
identify of the member), yaitu anggota sebagai pemilik dan sekaligus sebagai pengguna jasa koperasi (user own oriented firm).

\section{Standar Akuntansi Keuangan untuk Entitas Tanpa Akuntabilitas Publik (SAK ETAP)}

Standar Akuntansi Keuangan Entitas Tanpa Akuntabilitas Publik atau SAK ETAP merupakan standar akuntansi keuangan yang diperuntukkan bagi entitas tanpa akuntabilitas publik.SAK ETAP disahkan oleh 18 orang anggota Dewan Standar Akuntansi Keuangan pada tanggal 19 Mei 2009 di Jakarta. SAK ETAP terdiri atas 30 bab dan dilengkapi dengan daftar istilah di bagian akhir. Pernyataan Standar Akuntansi Keuangan Entitas Tanpa Akuntabilitas Publik (PSAK ETAP) akan dinyatakan efektif berlaku untuk entitas yang tidak memiliki akuntabiltas publik, yaitu entitas yang memiliki 2 kriteria, yaitu: Tidak memiliki akuntabilitas publik secara signifikan dan tidak menerbitkan laporan keuangan untuk tujuan umum bagi pengguna eksternal. Kriteria ETAP tersebut, bisa dibedakan dengan entitas yang memiliki akuntabilitas publik, yaitu jika:

1. Entitas telah mengajukan pernyataan pendaftaran atau entitas dalam proses pengajuan pernyataan pendaftaran pada otoritas pasar modal (BAPEPAM-LK) atau regulator lain untuk tujuan penerbitan efek di pasar modal;

2. Entitas menguasai aset dalam kapasitas sebagai fidusia untuk sekelompok besar masyarakat, seperti bank, entitas asuransi, pialang dan/atau pedagang efek, dana pensiun, reksa dana, dan bank investasi.

\section{Peraturan Menteri Koperasi Dan Usaha Kecil Dan Menengah Republik Indonesia Nomor 12/Per/M.KUKM/Ix/2015, Tentang "Pedoman Umum Akuntansi Koperasi"}

Berdasarkan pada Peraturan Menteri Koperasi Dan Usaha Kecil Dan Men-engah Republik Indonesia Nomor 12/Per/M.Kukm/Ix/2015,Tentang “Pedoman Umum Akuntansi Koperasi” pasal 3, maka setiap koperasi yang tidak memiliki akuntabilitas publik, maka dipersyaratkan laporan keuangannya mengacu kepada Standar Akuntansi Keuangan Entitas Tanpa Akuntabilitas Publik (SAK-ETAP). Laporan keuangan koperasi menyajikan informasi yang menyangkut kondisi, kinerja dan perubahan posisi keuangan koperasi, yang bermanfaat bagi pengambilan keputusan strategis untuk pengembangan koperasi tersebut. Koperasi harus menyajikan laporan keuangan secara lengkap dan disertai dengan lembar pernyataan tanggung jawab pengurus yang ditanda tangani diatas materai cukup oleh pengurus. Mengingat pemakai laporan keuangan koperasi adalah anggota koperasi, pengurus, pengawas serta stakeholder lain (pemerintah, kreditur dan pihak lain yang berkepentingan) maka laporan keuangan harus memenuhi ketentuan dalam penyajian kualitatif laporan keuangan, antara lain :

1. Kelangsungan Usaha (Going Concern)

Laporan keuangan harus disusun atas dasar kelangsungan usaha dan asumsi menurut seorang pembaca laporan keuangan, bahwa koperasi akan meneruskan operasionalnya dimasa depan kecuali apabila laporan keuangannya disusun untuk tujuan tertentu, seperti rencana pembubaran, penggabungan, peleburan dan pemisahan, maka harus diungkapkan dalam catatan atas laporan keuangan.

2. Komponen laporan keuangan koperasi

Koperasi harus menyajikan laporan pertanggung jawaban keuangan koperasi dalam bentuk laporan keuangan yang sekurang-kurangnya diterbitkan sebanyak 1 (satu) bulan sebelum kegiatan rapat anggota tahunan (RAT) diselenggarakan, berupa :
a. Neraca
b. Perhitungan Sisa Hasil Usaha
c. Laporan Perubahan Ekuitas.
d. Laporan Arus Kas
e. Catatan Atas Laporan Keuangan;

\section{Pengukuran Unsur-Unsur Laporan Keuangan Koperasi}

Pengukuran adalah proses penetapan jumlah uang yang digunakan entitas untuk mengukur aset, kewajiban, penghasilan dan beban dalam laporan keuangan. Proses ini termasuk pemilihan dasar pengukuran tertentu. Dasar pengukuran yang umum adalah biaya historis dan nilai wajar

\section{Dasar Akrual}

Entitas harus menyusun laporan keuangan, dengan menggunakan dasar akrual, kecuali laporan arus kas. Dalam dasar akrual, pos-pos diakui sebagai aset, kewajiban, ekuitas, penghasilan, dan beban (unsurunsur laporan keuangan) ketika memenuhi definisi dan kriteria pengakuan untuk pos-pos tersebut.

\section{Konsistensi Penyajian}


Penyajian dan klasifikasi pos-pos dalam laporan keuangan harus tetap sama (konsisten) dari periode ke periode berikutnya. Perubahan di dalam penyajian hanya diperbolehkan bilamana :

a. Standar mengharuskan perubahan dalam penyajian.

b. Terjadi perubahan yang signifikan dalam sifat operasi dari entitas, atau suatu kajian terhadap laporan keuangannya yang mengharuskan penggunaan penyajian, atau klasifikasi lainnya yang dianggap lebih memadai.

\section{Penyajian Laporan Keuangan menurut SAK-ETAP dan Peraturan Menteri K-UKM No 12 Tahun 2015 Neraca}

Neraca minimal mencakup pos-pos berikut:

(a) kas dan setara kas;

(b) piutang usaha dan piutang lainnya;

(c) persediaan;

(d) properti investasi;

(e) aset tetap;

(f) aset tidak berwujud;

(g) utang usaha dan utang lainnya;

(h) aset dan kewajiban pajak;

(i) kewajiban diestimasi;

(j) ekuitas.

\section{Perhitungan Hasil Usaha}

Pendapatan adalah penghasilan yang timbul dalam pelaksanaan aktivitas entitas yang biasa dan dikenal dengan sebutan yang berbeda seperti penjualan, imbalan, bunga, royalty dan pendapatan sewa.

1. Pendapatan dari Pelayanan Anggota

2. Pendapatan dari Pelayanan Non-Anggota

3. Harga Pokok Penjualan

4. Sisa Hasil Usaha Kotor

5. Beban Operasional

a. Beban Administrasi dan Umum,

b. Beban Perkoperasian

c. Beban Usaha,

6. Pendapatan dan atau Beban Lainnya.

7. Beban Pajak Badan

8. Sisa Hasil Usaha Setelah Pajak

\section{Laporan Arus Kas}

Laporan arus kas adalah laporan tentang arus masuk dan arus keluar uang tunai atau setara tunai. Laporan arus kas menyediakan informasi tentang perubahan uang tunai dan setara tunai dalam satu entitas untuk periode yang dilaporkan dalam komponen yang terpisah. Laporan arus kas terdiri dari :

a. Aktivitas Operasi, arus kas yang berasal dari aktivitas utama koperasi. Arus kas tersebut pada umumnya berasal dari transaksi dan peristiwa serta kondisi lain yang mempengaruhi besaran SHU

b. Aktivitas Investasi , arus kas penerimaan dan pengeluaran sehubungan dari sumber daya yang digunakan untuk tujuan menghasilkan pendapatan masa depan

c. Aktivitas Pendanaan, arus kas penerimaan dan pengeluaran yang berhubungan dengan sumber pendanaan untuk tujuan menghasilkan pendapatan masa depan.

\section{Laporan Perubahan Ekuitas}

Laporan perubahan ekuitas bertujuan menyajikan laba/rugi koperasi untuk suatu periode, pos pendapatan dan beban yang diakui secara langsung dalam ekuitas untuk periode tersebut, pengaruh kebijakan akuntansi dan koreksi kesalahan yang diakui dalam periode tersebut. Informasi yang disajikan di laporan perubahan ekuitas meliputi:

a. Sisa hasil usaha untuk periode;

b. Pendapatan dan beban yang diakui langsung dalam ekuitas; 
c. Pengaruh perubahan akuntansi dan koreksi kesalahan yang diakui, sesuai kebijakan akuntansi, estimasi, dan kesalahan untuk setiap komponen ekuitas;

d. Rekonsiliasi antara jumlah yang tercatat pada awal dan akhir periode untuk setiap komponen ekuitas, yang menunjukkan perubahan secara terpisah dari:

1. Sisa hasil usaha;

2. Pendapatan dan beban yang diakui langsung dalam ekuitas;

3. Jumlah SHU yang dibagikan dan distribusi lain untuk anggota, yang menunjukkan secara terpisah komponen simpanan anggota.

Adapun komponen-komponen Laporan Perubahan Ekuitas akan menunjukkan perubahan dari simpanan pokok, simpanan wajib, hibah, cadangan, sisa hasil usaha yang tidak dibagikan pada periode akuntansi.

\section{Catatan Atas Laporan Keuangan}

Catatan atas laporan keuangan koperasi harus memuat pengungkapan kebijakan koperasi yang mengakibatkan perubahan perlakuan akuntansi dan pengungkapan informasi lainnya. Perlakuan akuntansi yang harus diungkapkan atau diinformasikan antara lain :

c. Gambaran Umum Koperasi

d. Informasi tentang dasar penyusunan laporan keuangan

e. Kebijakan akuntansi tentang pengakuan, pengukuran dan perlakuan : transaksi dalam mata uang asing, kas dan setara kas, piutang, penilaian persediaan, biaya dibayar dimuka, aset tetap, pajak penghasilan, dan sebagainya, diantaranya :

1. Pengakuan, perlakuan dan kebijakan akuntansi mengenai aset tetap

2. Kebijakan akuntansi tentang persediaan

3. Kebijakan akuntansi mengenai piutang

f. Penjelasan yang mendukung pos-pos dan perhitungan sisa hasil usaha yang nilainya material (berdasarkan ketentuan pada masing-masing koperasi) sesuai dengan urutan penyajian setiap komponen laporan keuangan dan urutan penyajian pos-pos tersebut.

g. Catatan atas laporan keuangan koperasi harus jelas dan nyata, memuat informasi lain seperti :

1. Kegiatan usaha utama koperasi

2. Kegiatan pelayanan koperasi kepada anggota

3. Kegiatan bisnis koperasi dengan non anggota yang ditargetkan dan yang sudah dilaksanakan.

4. Informasi mengenai kegiatan bisnis koperasi dengan non anggota yang ditargetkan dan yang sudah dilaksanakan.

5. Aktivitas koperasi untuk mempromosikan ekonomi dan pengembangan kemampuan sumberdaya anggota melalui pendidikan dan pelatihan.

\section{Penelitian Terdahulu}

Nurdita (2012), dengan judul Analisis penerapan SAK ETAP pada Koperasi yang ada di Kota Dumai, tujuannya untuk mengetahui bagaimana penerapan SAK ETAP pada Koperasi-koperasi yang ada di Kota Dumai.Metode penelitian yang digunakan adalah metode deskriptif komparatif.Hasil dari penelitian diketahui Sebagian besar koperasiyang ada di kota Dumai sudah melakukan pelaporan keuangan sederhana namun hanya sebagian kecil yang sudah benar-benar menerapkan SAK ETAP ke dalam laporan keuangannya.Terdapat persamaan dan perbedaan dengan penelitian yang dilakukan.Persamaannya yaitu metode penelitian deskriptif.Perbedaanya pada objek penelitian.

Putra (2012), dengan judul Evaluasi Penerapan Standar Akuntansi Keuangan Entitas Tanpa Akuntabilitas Publik (SAK ETAP) Pada PT. TDMN Kudus, tujuannya untuk mengevaluasi penerapan SAK ETAP pada PT. TDMN Kudus.Metode penelitian yang digunakan adalah metode deskriptif komparatif. Hasil penelitian yang ditemukan PT. TDMN telah menyajikan Laporan Keuangan sesuai dengan kaidah SAK ETAP.Terdapat persamaan dan perbedaan dengan penelitian yang dilakukan. Persamaannya adalah sama-sama menggunakan metode analisis deskriptif komparatif.Perbedaannya pada objek penelitian. 


\section{METODE PENELITIAN}

\section{Jenis Penelitian}

Jenis penelitian ini adalah bersifat deskriptif komparatif, untuk mengetahui penerapan SAK ETAP dalam penyajian laporan keuangan KPRI Gelora Pendidikan Kota Tomohon.

\section{Tempat Penelitian}

Tempat penelitian dilakukan pada KPRI Gelora Pendidikan Kota Tomohon pada bulan Maret 2016. Jenis

\section{Data}

Jenis data yang digunakan dalam penelitian ini terbagi dua jenis yaitu :

a. Data Kualitatif adalah data yang berbentuk kata-kata, bukan dalam bentuk angka (non-numerik). Data kualitatif diperoleh melalui berbagai teknik pengumpulan data misalnya wawancara, analisis dokumen, diskusi terfokus, atau observasi.

b. Data kuantitatif adalah data yang berbentuk angka atau bilangan (numerik).

\section{Sumber Data}

Penelitian ini menggunakan sumber data sekunder yakni berupa laporan keuangan KPRI Gelora Pendidikan Kota Tomohon tahun 2015.

\section{Prosedur Penelitian}

Prosedur atau langkah-langkah penelitian yang dilakukan adalah sebagai berikut:

a. Menetapkan rumusan masalah;

b. Mengumpulkan teori-teori yang berhubungan dengan kajian yang berhubungan dengan SAK ETAP;

c. Mengumpulkan informasi mengenai gambaran umum Koperasi dan mengenai laporan keuangan pada KPRI Gelora Pendidikan Kota Tomohon;

d. Mencari data yang akan digunakan dalam penelitian;

e. Memberikan kesimpulan dan saran sehingga dapat menjadi masukan bagi pihak Koperasi

\section{Metode Analisis}

1. Deskriptif, Metode dimana data dikumpulkan, disusun, diinterpretasikan dan dianalisis sehingga memberikan keterangan yang lengkap bagi masalah yang dihadapi.

2. Komparatif, Metode analisis yang dilakukan dengan membandingkan teori-teori dan standar yang berlaku yaitu Standar Akuntansi Keuangan Entitas Tanpa Akuntabilitas Publik (SAK ETAP) dan Peraturan Menteri K-UKM No 15 Tahun 2016 dengan praktik yang terjadi di dalam KPRI Gelora Pendidikan Kota Tomohon, kemudian mengambil kesimpulan dari hasil perbandingan tersebut.

\section{Hasil Penelitian}

\section{HASIL PENELITIAN DAN PEMBAHASAN}

Koperasi Pegawai Republik Indonesia (KPRI) “Gelora Pendidikan" Kota Tomohon, adalah sebuah koperasi yang sudah lama berdiri di Kota Tomohon. KPRI Gelora Pendidikan didirikan pada tahun 1988. KPRI "Gelora Pendidikan" Kota Tomohon sudah melaksanakan RAT ke-27 untuk tutup buku tahun 2015. Pelaksanaan RAT yang konsisten adalah menjadi ciri bahwa KPRI "Gelora Pendidikan" Kota Tomohon dalam keadaan sehat. Keanggotaan koperasi ini sampai pada akhir tahun 2015 adalah 539 anggota yang kebanyakan anggotanya berasal dar latar belakang Pegawai Negeri Sipil, yaitu para guru-guru SD.

KPRI "Gelora Pendidikan" Kota Tomohon, mempunyai beberapa bidang usaha yang digeluti sebagai alat perputaran modal. Adapun bidang-bidang usaha yang digeluti oleh KPRI "Gelora Pendidikan" Kota Tomohon adalah sebagai berikut.

1. Jasa Simpan Pinjam (yang menjadi usaha dominan koperasi)

2. Waserda Non-Stok (penjulan beras dalam bentuk pinjaman)

3. Penjualan Gas Elpiji

4. Penyewaan penginapan (rumah kost)

Kebijakan-kebijakan akuntansi yang dilakukan oleh koperasi antara lain adalah sebagi berikut. 
1. Penyajian Laporan Keuangan

Laporan Keuangan disajikan sesuai dengan Pernyataan Standar Akuntansi Keuangan No. 27 "Akuntansi Koperasi” yang diterbitkan oleh ikatan Akuntan Indonesia. Laporan keuangan berdasarkan harga perolehan.

2. Penyisihan Piutang

Manajemen Koperasi melakukan Penyisihan Piutang Secukupnya

3. Persediaan

Pencatatan Persediaan menggunakan sistim fisik dan penilaian Persediaan menggunakan metote FIFO

4. Aktiva Tetap dan Penyusutan

Aktiva tetap dicatat berdasarkan nilai perolehan dan disusutkan berdasarkan metode prosentase tetap

5. Pendapatan Dan biaya

Pengakuan Pendapatan dan biaya menggunakan metode Acrual Basis.

Laporan keuangan diterbitkan KPRI "Gelora Pendidikan" Kota Tomohon terdiri dari laporan keuangan bulanan dan laporan keuangan tahunan, yang terbagi atas Neraca, Perhitungan Hasil Usaha, Catatan Atas Laporan Keuangan.

\section{Neraca}

Neraca pada KPRI Gelora Pendidikan Kota Tomohon dari aktiva, kewajiban dan ekuitas .

\section{Perhitungan Sisa Hasil Usaha}

Laporan Perhitungan Hasil Usaha yang disusun oleh KPRI "Gelora Pendidikan" Kota Tomohon terdiri dari tiga bagian, yaitu bagian A berisi Perhitungan Pendapatan-pendapatan, bagian B berisi Perhitungan Harga Pokok Penjualan dan bagian $\mathrm{C}$ berisi Perhitungan Beban-beban koperasi. Kemudian disusun dengan format $\mathrm{A}$ $-(\mathrm{B}+\mathrm{C})$

\section{Catatan Atas Laporan Keuangan}

CALK yang diterbitkan oleh KPRI "Gelora Pendidikan" Kota Tomohon berisi tentang penjelasan-penjelasan mengenai laporan keuangan yang dihasilkan. Adapun bagian-bagian dari CALK yang di terbitkan oleh koperasi ini terdiri dari

a. Informasi umum tentang Koperasi

b. Kebijakan Akuntansi

1) Dasar akuntansi dalam penyajian laporan keuangan

2) Metode Penyisihan Piutang

3) Metode Pencatatan Persediaan

4) Metode Pencatatan Aktiva Tetap beserta metode penyusutannya

5) Metode Pengakuan Pendapatan dan Beban

c. Penjelasan tentang Pos-Pos yang ada dalam Neraca.

\section{Pembahasan}

SAK ETAP diterbitkan oleh IAI dikhususkan untuk entitas-entitas kecil dan menengah serta koperasi. Tetapi ternyata dalam prakteknya SAK ETAP masih belum digunakan oleh secara utuh oleh UMKM dan Koperasi. Pada KPRI "Gelora Pendidikan" Kota TomohonDalam penyusunan laporan keuangannyapun masih berpatokan pada PSAK 27 tentang Akuntansi Koperasi yang sebenarnya sudah dihapus oleh IAI pada tahun 2010.Selain itu juga pemerintah lewat Kementrian Koperasi dan UMKM Republik Indonesia telah mengeluarkan Peraturan Menteri No. 12 Tahun 2015 Tentang Pedoman Umum Akuntansi Koperasi yang bertujuan membuat suatu pedoman bagi koperasi-koperasi yang ada dalam menyusun laporan keuangannya yang aturan-aturan dan standar-standarnya didasarkan pada SAK ETAP yang disusun oleh IAI.

\section{Neraca}

Dalam penyusunan laporan Neraca KPRI "Gelora Pendidikan" Kota Tomohon ternyata belum sepenuhnya sesuai dengan SAK ETAP dan Peraturan Menteri K-UMKM No. 12 Tahun 2015 Tentang Pedoman Umum Akuntansi Koperasi. Hal ini dikarenakan ada beberapa pos-pos yang belum di jelaskan dalam laporan keuangan yang diterbitkan seperti, Simpanan Anggota dan Utang Pajak. Yang semestinya harus dicantumkan 
dalam neraca. Ada juga pos-pos yang tidak dicantumkan karena memang tidak berhubungan langsung dengan kegiatan koperasi seperti Biaya Dibayar Dimuka, Properti Investasi dan Hibah.

Koperasi menyajikan Akun Aset Tetap dalam Neraca dengan perhitungan Harga Perolehan, dimana koperasi juga membuat Daftar Invetaris Aset Tetap lengkap dengan perhitungan Penyusutannya yang dimuat dalam Catatan Atas Laporan Keuangan (CALK). Adapun beberapa pos-pos dalam neraca yang lebih diperjelas oleh koperasi contohnya akun Cadangan, koperasi membagi akun cadangan ini kedalam beberapa akun, yaitu Cadangan Pemupukan Modal, Cadangan Resiko, dan Cadangan Dari SHU

\section{Perhitungan Sisa Hasil Usaha}

Koperasi menyajikan laporan Perhitungan Hasil usahanya dengan format total pendapatan Koperasi kemudian ditambah Harga Pokok Penjualan dan dikurangi biaya-biaya yang dikeluarkan koperasi. Sedangkan sesuai dengan SAK ETAP laporan harus menyertakan Pendapatan Anggota, Pendapatan Non-Anggota, sehingga menghasilkan Sisa hasil Usaha Kotor, kemudian dikurangi Beban-beban Kemudian dikurangi Pajak penghasilan dan menghasilkan Sisa Hasil Usaha Setelah Pajak.

\section{Catatan Atas Laporan Keuangan}

Catatan Atas Laporan Keuangan yang diterbitkan oleh koperasi adalah laporan yang berisi tentang gambaran umum koperasi, struktur kepengurusan, pengawas, jenis-jenis usaha yang dijalankan, kebijakankebijakan akuntansi yang diterapkan penjelasan pos-pos neraca, penjelasan perhitungan sisa hasil usaha, pembagian shu dan informasi-informasi tentang koperasi lainnya. Catatan Atas Laporan Keuangan yang diterbitkan oleh KPRI "Gelora Pendidikan" Kota Tomohon jika dibandingkan dengan SAK ETAP dan Peraturan Menteri No. 12 Tahun 2015, masih belum lengkap karena ada beberapa item yang belum dijelaskan oleh koperasi dalam laporan CALK. Koperasi tidak mencantumkan sejarah koperasi, penjelasan tentang dasar penentuan penyisihan piutang tak tertagih, penjelasan tentang perhitungan sisa hasil usaha, dan penjelasan tentang pembagian sisa hasil usaha. Oleh karena itu peneliti beranggapan bahwa penerbitan catatan atas laporan keuangan oleh KPRI "Gelora Pendidikan" Kota Tomohon belum sepenuhnya sesuai dengan SAK ETAP dan Peraturan Menteri No. 12 Tahun 2015 tentang Pedoman Umum Akuntansi Koperasi.

Hasil penelitian ini didukung oleh penelitian sebelumnya Pratiwi (2014) yang menyimpulkan bahwa laporan keuangan PT. Nichindo tidak sesuai dengan SAK ETAP dikarenakan penyebab tidak diterapkannya SAK ETAP pada pelaporan keuangan UMKM adalah karena kurangnya pengetahuan akan SAK ETAP oleh pelaku usaha. Dan hasil penelitian oleh Singal (2016) yaitu dalam penyusunan laporan laba rugi dan neraca pada PT. Karunia Multi Guna Abadi,bahwa masih terdapat beberapa ketidaksesuaian dengan kaidah peyajian laporan keuangan menurut SAK ETAP (2009). Serta penelitian oleh Sari (2014) yaitu PR. Trubus Alami belum meyajikan laporan keuangan yang sesuai dengan SAK ETAP. Laporan laba rugi dan neraca yang disajikan masih belum sesuai dengan SAK ETAP.

\section{Kesimpulan}

\section{PENUTUP}

Hasil analisis dan penelusuran terhadap KPRI Gelora Pendidikan Kota Tomohon mengenai penyajian laporan keuangan berdasarkan SAK ETAP (2009) diperoleh kesimpulan bahwa: Dalam penyajian laporan keuangannya pada KPRI Gelora Pendidikan Kota Tomohon masih terdapat beberapa ketidaksesuaian dengan kaidah penyajian laporan keuangan menurut SAK ETAP (2009). Adapun hal-hal yang membuat koperasi ini memiliki kekurangan dalam penyusunan laporan keuangannya, sesuai dengan pernyataan pihak manajer koperasi yaitu dikarenakan oleh beberapa faktor antara lain; kurangnya tenaga kerja yang terampil dan ahli dalam akuntansi, kurangnya sosialisasi dari pemerintah dan pihak-pihak terkait tentang penerapan SAK ETAP (2009), dan kurangnya pengetahuan dalam laporan keuangan yang termasuk dalam SAK ETAP 2009.

\section{Saran}

Berdasarkan penelitian yang telah dilakukan, berikut ini adalah saran atau rekomendasi yang diberikan oleh penulis :

1. Bagi Koperasi yakni KPRI "Gelora Pendidikan" Kota Tomohon

a. Dalam menyusun laporan keuangannya koperasi sebaiknya berpedoman pada SAK ETAP dan Peraturan Menteri K-UMKM No. 12 Tahun 2015 dan tidak lagi berpedoman pada PSAK No. 27. 
b. Koperasi sebaiknya menerbitkan laporan keuangan sesuai dengan dengan SAK ETAP dan Peraturan Menteri K-UMKM No. 12 Tahun 2015 secara lengkap (Neraca, Perhitungan Hasil Usaha, Laporan Arus Kas, Laporan Perubahan Ekuitas, dan Catatan Atas Laporan Keuangan).

c. Sebaiknya koperasi mempekerjakan staf khusus yang paham dan memiliki keahlian dalam bidang akuntansi.

2. Bagi Koperasi Jasa Audit (KJA) "Pembina" Sulawesi Utara, selaku auditor yang mengaudit Koperasi ini, seharusnya melakukan audit kepada koperasi-koperasi sesuai dengan SAK ETAP dan Peraturan Menteri KUKM No 12 Tahun 2015 dan mengarahkan kepada koperasi-koperasi untuk menyusun laporan keuangannya sesuai dengan SAK ETAP dan Peraturan Menteri K-UKM No 12 Tahun 2015.

3. Bagi Ikatan Akuntan Indonesia (IAI) dan Kementerian Koperasi dan UMKM Republik Indonesia. Sebaiknya memberikan sosialisasi terbuka mengenai penyusunan laporan keuangan koperasi yang berdasarkan pada SAK ETAP dan Peraturan Menteri K-UMKM No. 12 Tahun 2015 bagi koperasi-koperasi yang ada diseluruh Indonesia.

4. Bagi Perguruan Tinggi

Sebaiknya dapat ikut melakukan sosialisasi, penyuluhan dan pelatihan mengenai penerapan SAK ETAP dan Peraturan Menteri K-UMKM No. 12 Tahun 2015 bagi koperasi sebagai bentuk Tri Dharma Perguruan Tinggi.

\section{DAFTAR PUSTAKA}

Abrory Agnesti. 2010. Analisis faktor-faktor yang mempengaruhi Kebutuhan Standar Akuntansi Keuangan Entitas Tanpa Akuntabilitas Publik (SAK ETAP) bagi Usaha Kecil dan Menengah (UKM) (Studi Kasus pada UKM Marmer / Onix di Kabupaten Tulungagung Jawa Timur.

Bataineh, Ibrahem Mohamed Al. 2012. The implementation of Financial Accounting Standard for Small and Medium Enterprises in Jordan. Interdisciplinary Journal of Contempory Research in Bussiness.

Herman Adhi Putra. 2012. Evaluasi Standar Akuntansi Keuangan Entitas Tanpa Akuntabilitas Publik Pada PT. $T D M N$.

Ikatan Akuntan Indonesia. 2009. Standar Akuntansi Keuangan Entitas Tanpa Akuntabilitas Publik. Jakarta. Dewan Standar Akuntansi Keuangan. $182 \mathrm{hlm}$.

JM. Jastra. 2011. Determinants Of Business Success Of Small and Medium Enterprices. Vol.2 No.20; November 2011. Iraq University Islamabad, Pakistan.

Khafid. 2012. Akuntansi Koperasi Berbasis SAK ETAP Pada Koperasi Petani Karet Karya Harapan (KOPTAN-KKH) Rokan Hulu. Universitas Pasir Pengaraian.

Kieso, Donald E., Weygandt, Jery J., Warfield. 2010. Akuntansi Intermediate. Terjemahan Emil Salim. Jilid I. Edisi Kesepuluh. Erlangga. Jakarta.

Martani, Dwi., Veronica NPS, Sylvia., Wardhani, Ratna.,Farahmita, Aria., Tanujaya, Edward. 2012. Akuntansi Keuangan Menengah. Berbasis PSAK. Penerbit Salemba Empat. Jakarta.

Mulyani. (2013). Penerapan Standar Akuntansi Keuangan Entitas Tanpa Akuntabilitas Publik (SAK ETAP) pada Koperasi KUD Tri Karsa Jaya Kec. KUD Tri Karsa Jaya Kec. Bangsalsari Kab. Jember KUD Tri Karsa Jaya Kec. Bangsalsari Kab. Jember.

Nurdita. 2012. Analisis Penerapan Standar Akuntansi Entitas Tanpa Akuntabilitas Publik (SAK ETAP) Pada Koperasi yang ada di Kota Dumai.

Peraturan Menteri Koperasi Dan Usaha Kecil Dan Menengah Republik Indonesia Nomor 12/Per/M.Kukm/IX/2015 Tentang Pedoman Umum Akuntansi Koperasi dan Koperasi Sektor Riil. Indonesia.

Pratiwi. 2014. Analisis Penerapan SAK ETAP pada penyajian laporan keuangan PT. Nichindo Manado Suisan. Universitas Sam Ratulangi Manado.

Reeve, James M., Warren, Carl S., Duchac, Jonathan E., Wahyuni, Ersa Tri., Soepriyanto, Gatot., Jusuf, Amir Abadi., Djakman, Chaerul D. 2009. Priciples of Accounting - Indonesia Adaption. Buku Pertama. Penerbit Salemba Empat.

Sangadji, Etta Mamang, Sopiah. 2011. Metodelogi Penelitian Pendekatan Praktis dalam Penelitian. Yogjakarta. Sitorus, 2011. Evaluasi Penerapan SAK ETAP dalam Penyusunan Laporan Keuangan pada KUD Jaya Pelita Medan. Universitas Sumatera Utara.

Shok, Irina Akhmedovna. 2013. International Financial Reporting Standard and Russian Accounting Standard and Effects of Those Differences on Finance Result of Western European Company Operating in 
Russia. Middle-East Journal of Scientific Research.Belgorod State National Research University, Belgorod, Russia.

Suhayati, Ely., Anggadini, Sri Dewi. 2009. Akuntansi Keuangan. Edisi Pertama. Penerbit Graha Ilmu.

Yogyakarta.

Supardi, 2013.Aplikasi Statistika dalam Penelitian. Smart. Jakarta

Turban, (2012). Penerapan SAK ETAP Pada Laporan Keuangan Usaha Mikro, Kecil dan Menengah (Studi Pada Usaha Sari Apel Kotabatu).

Undang-Undang No. 17 Tahun 2012 Tentang Perkoperasian. Indonesia

Yahya, Uthman. 2014. Financial Accounting Standard for Small and Medium Enterprises. Mediterranean Journal of Social Sciences Northwest University. Vol.6.

\section{LAMPIRAN}

Tabel 1. Checklist Kelengkapan Neraca

\begin{tabular}{|c|c|c|c|c|}
\hline \multirow{2}{*}{ No. } & \multicolumn{2}{|c|}{ Pos-Pos Akun dalam Neraca } & \multirow{2}{*}{ Ada } & \multirow{2}{*}{ Tidak Ada } \\
\hline & SAK ETAP & Permen K-UMKM & & \\
\hline \multirow{3}{*}{1} & \multirow{3}{*}{ Kas dan Setara Kas } & Kas & \multirow{3}{*}{$\sqrt{ }$} & \\
\hline & & Bank & & \\
\hline & & Surat Berharga & & \\
\hline 2 & Piutang Usaha dan Piutang Lainny & Piutang Usaha & $\sqrt{ }$ & \\
\hline 3 & Persediaan & Persediaan & & $\sqrt{ }$ \\
\hline \multirow{2}{*}{4} & & Biaya dibayar dimuka & & $\sqrt{ }$ \\
\hline & & Pendapatan & & $\sqrt{ }$ \\
\hline \multirow{2}{*}{5} & & Properti Investasi & $\sqrt{ }$ & \\
\hline & & \multicolumn{2}{|l|}{ Akumulasi Penyusutan Properti Investasi } & $\sqrt{ }$ \\
\hline \multirow{5}{*}{6} & \multirow{5}{*}{ Aset Tetap } & Tanah & \multirow{4}{*}{$\sqrt{ }$} & \\
\hline & & Bangunan & & \\
\hline & & Mesin dll & & \\
\hline & & Inventaris Kantor & & \\
\hline & & Akumulasi Penyusutan Aset Tetap & $\sqrt{ }$ & \\
\hline \multirow{2}{*}{7} & \multirow{2}{*}{ Aset Tidak Berwujud } & Aset Tidak Berwujud & & \multirow{2}{*}{$\sqrt{ }$} \\
\hline & & Akumulasi Amortisasi AsetTidak Berwujud & & \\
\hline \multirow{7}{*}{8} & \multirow{7}{*}{ Utang Usaha dan Utang Lainnya } & Utang Usaha & $\sqrt{ }$ & \\
\hline & & Simpanan Anggota & & $\sqrt{ }$ \\
\hline & & Dana SHU & $\sqrt{ }$ & \\
\hline & & Utang Bank & $\sqrt{ }$ & \\
\hline & & \multicolumn{2}{|l|}{ Utang Jangka Pendek Lainnya } & $\sqrt{ }$ \\
\hline & & Beban YMH dibayar & $\sqrt{ }$ & \\
\hline & & \multicolumn{2}{|l|}{ Pendapatan dibayar dimuka } & $\sqrt{ }$ \\
\hline 9 & Kewajiban Pajak & Utang Pajak & & $\sqrt{ }$ \\
\hline 10 & Kewajiban diestimasi & & & $\sqrt{ }$ \\
\hline \multirow{5}{*}{11} & \multirow{5}{*}{ Ekuitas } & Simpanan Pokok & $\sqrt{ }$ & \\
\hline & & Simpanan Wajib & $\sqrt{ }$ & \\
\hline & & Hibah & & $\sqrt{ }$ \\
\hline & & Cadangan & $\sqrt{ }$ & \\
\hline & & SHU & $\sqrt{ }$ & \\
\hline
\end{tabular}

Sumber : Hasil Olahan Data 
Format Laporan Perhitungan Sisa Hasil Usaha KPRI Gelora Pendidikan Kota Tomohon

\begin{tabular}{|c|c|c|}
\hline $\begin{array}{r}\text { KPRI "GELORA PENDIDIK } \\
\text { PERHITUNGAN SISA } \\
\text { PER } 31 \text { DESEM }\end{array}$ & $\begin{array}{l}\text { OMC } \\
\text { IHA }\end{array}$ & \\
\hline PENDAPATAN & & \\
\hline Partisipasi Jasa Pinjaman & $\mathrm{xxx}$ & \\
\hline Partisipasi Jasa Profisi & $\mathrm{xxx}$ & \\
\hline Penjualan Beras & $\mathrm{xxx}$ & \\
\hline Penjualan Gas Elpiji & $\mathrm{xxx}$ & \\
\hline Sewa Wisma Kost & $\mathrm{xxx}$ & \\
\hline Lain-lain & $\mathrm{x} \times \mathrm{x}$ & \\
\hline Jumlah (A) & & $x x x$ \\
\hline HARGA POKOK PENJUALA & & \\
\hline HPP Beras & $\mathrm{xxx}$ & \\
\hline HPP Gas Elpiji & $\mathrm{xxx}$ & \\
\hline Jumlah (B) & & $x x x$ \\
\hline BEBAN BIAYA & & \\
\hline Bunga Bank dan Deposito & $\mathrm{xxx}$ & \\
\hline Gaji dan Honor & $\mathrm{xxx}$ & \\
\hline Beban Transportasi & $\mathrm{xxx}$ & \\
\hline Beban Kantor & $\mathrm{xxx}$ & \\
\hline Beban Operasional & $\mathrm{xxx}$ & \\
\hline Penyisihan Piutang & $\mathrm{xxx}$ & \\
\hline Penyusutan Aktiva Tetap & $\mathrm{xxx}$ & \\
\hline Biaya RAT & $\mathrm{xxx}$ & \\
\hline Biaya Audit & $\mathrm{xxx}$ & \\
\hline THR & $\mathrm{xxx}$ & \\
\hline Beban Umum dan Lain-lain & $\mathrm{xxx}$ & \\
\hline Jumlah $(C)$ & & $x x x$ \\
\hline SISA HASIL USAHA & & $\mathbf{x x x}$ \\
\hline
\end{tabular}

Format Laporan Perhitungan Sisa Hasil Usaha

Menurut SAK ETAP dan PERMEN No. 12 Tahun 2015

KPRI "GELORA PENDIDIKAN" KOTA TOMOHON PERHITUNGAN SISA HASIL USAHA

PER 31 DESEMBER 2015

\begin{tabular}{|c|c|c|}
\hline \multicolumn{3}{|l|}{ PENDAPATAN } \\
\hline Pendapatan Anggota & $\mathrm{xxx}$ & \\
\hline HPP Anggota & $\mathrm{xxx}$ & \\
\hline Pendapatan Neto Anggota & $\mathrm{xxx}$ & \\
\hline \multicolumn{3}{|l|}{ PENDAPATAN NON-ANGGOTA } \\
\hline Pendapatan dan Penjualan & $\mathrm{xxx}$ & \\
\hline HPP Non-Anggota & $\mathrm{XXX}$ & \\
\hline Laba (Rugi) Kotor Non Anggota & $\mathrm{xxx}$ & \\
\hline SISA HASIL USAHA KOTOR & & $x x x$ \\
\hline \multicolumn{3}{|l|}{ BEBAN OPERASIONAL } \\
\hline Beban Usaha & $\mathrm{xxx}$ & \\
\hline Beban Perkoperasian & $\mathrm{xxx}$ & \\
\hline Beban Administrasi dan Umum & $\mathrm{xxx}$ & \\
\hline Total Beban Operasional & $\mathrm{xxx}$ & \\
\hline SHU Operasional & & $x \boldsymbol{x x}$ \\
\hline PENDAPATAN DAN BEBAN LAIN-LAIN & & \\
\hline -Pendapatan Lain-lain & $\mathrm{xxx}$ & \\
\hline -Beban lain-lain & $\mathrm{XxX}$ & \\
\hline SHU sebelum bunga dan pajak & & $\mathbf{x x x}$ \\
\hline Beban Bunga & $\mathrm{XXX}$ & \\
\hline SHU Sebelum Pajak & & $\mathbf{x x x}$ \\
\hline Pajak Penghasilan & $\mathrm{xxx}$ & \\
\hline SHU SETELAH PAJAK & & $\mathbf{x x x}$ \\
\hline
\end{tabular}

